\title{
The Role of Citizens Education in Forming The Character of Global Citizens
}

\author{
Amar Ma'ruf ${ }^{1, *}$, Marzuki Marzuki ${ }^{2}$ \\ ${ }^{1,2}$ Departemen of Pancasila dan Kewarganegaraan, Faculty of Social Science, Universitas Negeri Yogyakarta, \\ Indonesia \\ *Corresponding author. Email: amarmaruf.2019@student.uny.ac.id
}

\begin{abstract}
This study aims to find the character values of global citizens in civic education. This study uses a descriptive qualitative approach. There are two sources of data used in this study, namely primary data and secondary data. Primary data is obtained from respondents who are selected based on the intended research, while secondary data is obtained from books, journals, and various scientific studies related to research. Data collection techniques using interviews and documentation. Data analysis using inductive analysis. The results of this study are, first of all, the realization of social responsibility, global competence and global citizen skills that every citizen must possess.
\end{abstract}

\section{Keywords: Citizenship Education, Character, Global Citizens.}

\section{INTRODUCTION}

The era of the industrial revolution 4.0 allows people from all walks of life to be able to reach any information from any part of the world. This allows everyone to have sufficient skills to face the rapid development of the times, especially skills towards technology. Getting here, almost all human activities that are usually carried out physically are turning to digitalist ways, all of that is due to the role and emergence of the industrial revolution era 4.0 (advanced technology). The rapid development of the times provides space for the creation of two impacts, namely the positive and negative impacts of technological sophistication. It is undeniable that technological developments that are happening now provide a lot of convenience for humans to do everything without having to exert more physical strength. The development of the times, one of which is the internet can also act as a forum for exchanging information and ideas for citizens and the government [1]. But on the other hand, this also causes a syndrome in humans which results in increased laziness in humans to do everything (want to be instant) and ignore the process that must be passed as it should. The dominance of technology that makes the world borderless in this era of industrial revolution 4.0 not only makes it easy to get in and out of information from other countries, but also becomes a challenge for each country.
The rapid development of technology in the era of globalization or more familiarly called by the millennial generation as the era of industrial revolution 4.0 is a new challenge for all countries in the world, especially in developing countries. With the speed of information and perceived technological sophistication, all aspects of life can be reached and seen by anyone. Information that comes one after another will be able to have an impact on the lives of citizens around the world. Lifestyles, ideologies, beliefs and beliefs that develop in a country will be able to influence patterns and lifestyles in established countries. As a result, the noble values that were originally held firmly by citizens seemed to be eroded by the entry of culture and customs from developed countries and were adopted without being filtered by citizens who live in the vortex of developing countries. Examples of lifestyles that can be influenced by developed countries from the west are the consumerism, individualistic and hedonistic nature of citizens living in the east who previously had a polite style and had a high sense of collectivism.

In the context of citizenship, everyone has a role as a citizen who has the rights and obligations in the country that the person is living in. A citizen must also be a pillar for his country in various ways, especially in making the country as something that is known throughout the world. In Indonesia, there are many things that citizens can do to make this country known throughout the world, be it through its culture, sports 
achievements, scholarship, scientific works and others. However, to get to that point, every citizen must have global and international skills so that being able to support the existence of a citizen is also a provision to keep abreast of the times, especially to make his country of origin better known throughout the world. However, with the speed of information like what is happening today, it is again a problem in itself, not only for the country but also for the younger generation. This hedonic and consumptive lifestyle is very easy and fast to be followed by today's young generation, moreover because the guidance that exists on social media requires the younger generation to have all kinds of equipment that must support it. As a result, the basic values that were originally held firmly will eventually begin to erode if this is left unchecked.

The problem of the tendency of global life which has begun to erode the noble values of the nation needs to be faced and a solution formulated to fend off the bad things that are caused. One way that can be taken to find a way out of this problem is to strengthen the noble values of the nation which are used as the basis for living as a nation and state through educational spaces, especially in civic education. Citizenship education has an important role in improving the insight and character of global citizens. Citizenship education is not only limited to learning about the rights and obligations of citizens in a country, but more than that civic education has a wider scope, including also in preparing global citizens. Civic education provides a complex approach that aims to strengthen students to be ready to take on the role of responsible adult global citizens [2].

\section{THEORETICAL REVIEW}

The concept of global citizenship tends to make people or citizens more flexible in being citizens. The flexibility shown is by not being too fixated on one nation state, but more welcoming to culture and diversity outside of its own citizenship (Cosmopolis). Specific conceptualizations may vary, but one of the most prominent manifestations of cosmopolitanism is the feeling of belonging or territorial attachment to a world that transcends the nation-state [3]. Becoming a global citizen can also be done by combining education with certain forms of civic participation, so that the country is strategically considered to have invested in developing human resources through education, on the other hand, it is also important to link financial literacy with citizenship. it will also have an impact on economic development and global knowledge in one country [4\&5]. While reflexivity, relationality, criticality, and social imagination are tools and fuels of a global mindset for moral and transformative reasoning [6].

In developing countries such as Indonesia, to achieve the character of a global citizen does not necessarily manifest itself, but it must have a system that encourages the creation of a global citizen character. Global citizenship requires an awareness of the interdependence of individuals and systems and a sense of responsibility that follows [7]. As stated by [8] recognition of intercultural interdependence includes navigating the dangerous waters of interdependence between individuals which requires the sequential movement of individuals and communities through the following phases: (a) enhancing/enhancing intercultural communication, (b) inclusive cross-cultural encounters. culture, (c) increasing cultural awareness (first one's culture, then another's culture, and finally many other cultures), (d) realization of a common destiny and the need to find common solutions that benefit all.

One way that can be done to shape the character of global citizens is through citizenship education. Civic education has a scope that is following the global citizenship mission, because in citizenship education it is not only about national citizenship, but also international. The purpose of civic education is to foster a caring, wise, participatory and contributive attitude towards the development of society and the state with a patriotic and democratic spirit [9]. Although in general in education it is often the case that the analytical framing of education as a space of subjectification relies too much on the assumption that schools must be enclosed in a disciplinary space and treat learning as a predictable outcome [10]. With the existence of civic education, preparing global citizens is one thing that needs to be considered. The emphasis on preparation for citizenship in the national context fosters the character of global citizens, including student identification with and loyalty to the national community [11]. Thus, the formation of a global citizen character will provide space for students as well as teachers to jointly identify the extent of a citizen's loyalty to his national community.

As learning that is flexible in terms of national and international perspectives, civics education must be a great foundation for all elements involved in shaping the character of global citizenship, both teachers and students in schools or even lecturers and students at the higher education level. Citizenship education must also be able to encourage social sensitivity of citizens both at local and global levels as described in the preamble to the 1945 Constitution of the Republic of Indonesia that every citizen must not only participate in protecting the entire nation and educating the nation's life, but also participate in maintaining world order and lasting peace. Attitudes and behaviors that are instilled in such a way will lead civic education into learning that has a central role in shaping global citizenship by not forgetting the identity of a citizen of his own country. The formation of the character of global citizens is expected to be able to realize the social responsibility of citizens for various things both inside and outside their own country, and have global competencies and skills that are following the times. What a citizen must have as a member of a country and as a member of a world citizen. 


\section{METHOD}

This study uses a qualitative descriptive approach by exploring the required data in depth with qualitative analysis and does not use statistical calculations. This type of research is phenomenological research, namely research that aims to discuss and describe everything phenomenal or currently happening so that it needs to be researched and studied and analyzed to obtain renewable research results following existing progress. This study discusses the phenomenon of the emergence of global citizenship issues that require competence and skills to become part of global citizens and how the role of civic education is to arrive at the stage of forming the character of global citizens. There are two sources of data used in this study, namely primary and secondary data. Primary data are respondents who are selected by researchers to fulfill and obtain data following the research conducted. The primary data in question include students, teachers, and lecturers who are involved in the world of civic education. Meanwhile, secondary data is complementary data which is a reference source. Secondary data is obtained from books, journals, and various scientific studies that support and relate to research. Data collection techniques used in the study were interviews and documentation. While the data analysis used is to do inductive analysis.

\section{DISCUSSION}

\subsection{Citizenship Education}

Civic education is an important pillar that must be strengthened to form global citizenship. In the context of the curriculum in Indonesia, civics education is a compulsory subject at every level of education, from elementary, junior high, high school to university. The hope is that civic education can prepare global citizens who have certain abilities and skills so that they can actively participate in global society. [12] stated that two roles can be played to be included in the category of global citizens. First, educators must be able to improve the skills, knowledge and attitudes of students deeply and universally. the second reinforces moral values and empathy in addition to individual and group interests. [13] that educators, especially in the 21 st century era, are competing to improve the quality of students so that they become global citizens by developing student competencies about awareness of living in a world that is considered more just, tolerant and peaceful.

Citizenship education in the most general perspective has a contribution to foster and develop the character of an intelligent citizen. This, of course, has become an important idea, plan and hope in civic education. Citizenship education is a learning platform that can print the character of students to become part of global citizens. Civic education is one way to train the knowledge, attitudes and skills of citizens to be able to actively participate and be part of solving global problems that occur through applied learning patterns. [14] illustrates that civic education has been realized in five statuses, namely; The first is as a subject that is developed and contained in the curriculum at every level of education. Second, citizenship education is a general course (MKU) which is required at the university level. Third, it is included in the framework of social science disciplines in the teacher education program that is fostered and developed by the study program. Fourth, entering the realm of political education which was packaged in P4 upgrading in the 1970-1990s which was managed and regulated by the government. Fifth, Citizenship Education as a conceptual framework, in the form of individual thoughts or related expert groups and developed as a basis and framework for thinking about civic education.

The concept of civic education is not separated from the concept of the emergence of a global citizen. The emergence of globalization indirectly gives a signal that civic education must aim to create or prepare citizens who are ready to take part in globalization (Global citizens) and have various supports to become global citizens. Thus the idea of global citizenship becomes the main goal in civic education to develop the basic values of world citizens which is carried out through strengthening awareness of the rights and obligations that must be carried out by world citizens. Equal rights and obligations of citizens in carrying out their duties as citizens are not limited by territorial areas, which is the main concept of global citizenship [15]. The level of unity and integrity of various nations and countries is when there are problems that include public interests related to the rights and obligations of global citizens [16]. This in the end will be a trigger for the community to declare themselves as part of the world's state as a representation of power to increase global interests.

Based on the theory and research conducted by the author, civic education does have a vital role in shaping the character of global citizens. The formation of the character of global citizens can create quality citizens not only in the local context but also in the international context both in the knowledge, attitudes and behavior of a citizen. based on the analysis conducted by the author that civic education plays an important role in shaping the character of global citizens, so that state representatives, especially Indonesia, can carry out the mandate contained in the 1945 Constitution of the Republic of Indonesia, namely "to educate the life of the nation and participate in carrying out world order". From this analysis, citizens of course must have social responsibility as citizens of the world by always actively participating in every issue and problem that occurs globally.

\subsection{Global Citizens}

Global issues regarding the involvement of citizens in every global activity (globalization) have become a discourse that is quite busy being discussed among academics. In addition to being an interesting study, the 
participation of citizens in global dynamics is also an important concern that must be carefully observed and monitored. What do citizens need to have to be able to compete in the global region and how can a citizen be further involved in the global arena. That way, a citizen must have at least the character as a citizen, which gives his characteristics as a citizen. The character of a citizen is a characteristic of thoughts and habits that support social functions and guarantee the public interest and has an attitude that supports the effectiveness of political participation, the implementation of a healthy political system and the dignity of development and the public interest [17\&18]

Some of the things described will also support the emergence of citizenship skills. As described in the [19] civic competence combines knowledge, skills, attitudes and values to enable people to carry out their duties in the real world, such as active civic participation, including communication skills, problem solving, critical and creative reflection, decision making, responsibility. responsibility, and other values Respect, including awareness of attitudes and values of diversity, unity, human rights, equality and democracy. The citizenship competencies in question include describing the attitudes of self-efficacy and citizenship norms needed by individuals to become competent and effective active citizens, active participation in public affairs, equality among citizens, solidarity, tolerance, and the ability to cooperate with others. This can be tested for knowledge of civic-related content, skills in material interpretation, concepts, attitudes, and actions related to citizenship [20, 21, 22].

\section{CONCLUSION}

Based on the theory, data and analysis carried out by the researcher that civic education has a very fundamental role in shaping the character of global citizens. Based on this analysis, global citizens can be interpreted as individuals who have more sensitivity to all kinds of issues that apply globally. This sensitivity is obtained by the qualified insight of a citizen regarding various kinds of issues that apply globally through knowledge which is then sharpened with critical reasoning as part of the citizens of the world. This is part of the important role of civic education in providing sufficient global insight and skills for every citizen in the world. There characteristics of citizens must be owned by every citizen so that they can be categorized as global citizens, namely the first realization of social responsibility in everyday life. Both have global competence, both scientific competence, knowledge expertise and technology. The third is having global citizenship skills that every citizen must have, namely 21 st century skills.

\section{REFERENCES}

[1] B. J. Kim, A. L. Kavanaugh \& K. M. Hult 2011. Civic engagement and internet use in local governance: Hierarchial linear models for understanding the role of local community groups. Administration \& Society, 43 (7), 807-835.

[2] L. Bourke, P. Bamber, dan, M. Lyons. (2012). Global citizens: who are they? education, citizenship and social justice, 7 (2), 161-174.

[3] M. Zhou . (2016). Socal and individual sources of self-indentification as global citizens: Evidence from the interactive multilevel model. Sociological perspective, 59(1), 153-176.

[4] M Hantzopoulos \& S. Shirazi (2014). securing the state through the production of 'global' citizens: analyzing neo-liberal educational reforms in Jordan and the USA. Policy futures in education, 12(3), 370-385.

[5] T. Lucey \& Bates. (2012). Conceptually and developmentally aproproate education for financially literate

[6] Lilley. Barker \& Harris. (2015). Exploring the process of global citizen learning and the student mind-set. Jurnal of studies in international education, 19(3), 225-245.

[7] Roberts, Solya \& Al-Khanji. (2013). Preparing global citizens. Jurnal of collage and character, 14(1), 1-8.

[8] H. Altinay. (2010). The case for global civics. Global economy and development working paper 35. Retrieved from www. brookings.edu/papers/2010/03_global_ civics_altinay.aspx

[9] F.H. Adams, S. Andoh \& A. M. Quarshie. (2013). Effective teaching of citizenship education in primary schools in ghana. Journal of Education and Practice, 4(10), 18-23.

[10] J. Pykett, P. Cloke, C. Barnett, N. Clarke, A. Malpass. (2010). Learning to be global citizens: The rasionalities of fair-trade education. Enviromental and planing D: society and space. 28 (3), 487-508.

[11] A. Mullen (2012). Toward a global perspective on preparing global citizens. Theoty and research in social educatiom. 34(1), 146-152.

[12] A. Hadi (2019). Moralitas Pancasila dalam konteks warga negara global: mengkaji pendidikan kewarganegaraan untuk penguatan nilai moral dalam konteks globalisasi. Jurnal intelektualita: Keislaman, sosial dan sains, 8 (2), 1-16.

[13] D. S. Jeffrey (2012). The moral education of global citizens, Society 49 (6) 541-546.

[14] U S. Winataputra (2015) Pendidikan Kewarganegaraan Refleksi Historis Epistimologi 
Dan Rekonstruksi Untuk Masa Depan. Banten: Universitas Terbuka, 2015.

[15] M. Gerzon. (2010). American citizen, global citizen. Spirit Scope LLC.

[16] A. Hater (2014). Brief History of Citizenship. Edinburgh: Edinburgh University Press.

[17] C. N. Quigley, J. J. H. Buchanan, \& Bahmuler, C. F. Bahmuler. (1991). Civitas: a framework for civic education. Calabasas : CCE.

[18] E. Susanto. (2015). Pengaruh pembelajaran, habituasi, dan ekstrakurikuler terhadap pengembangan civic disposition siswa di sma negeri se-kota bandar lampung. Retrieved from http://repository.upi.edu/16014/
[19] E. E. Council. (2016). Fostering civic competence amongst students. Retrieved from http://www.civicoproject.eu/project en.php

[20] G. Almond \& S. Verba. (1963). Civic Culture. Princeton, NJ: Princeton University Press.

[21] R. D. Putnam, R. Leonardi \& R.Y. Nanetti. (1993). Making. democracy work: civic traditional in modern Italy. Princeton, NJ: Pricenton University Perss.

[22] B. Hoskins, M. Saisana \& C.m.h. Villalba (2015). Civic competence of youth in europe: measuring cross national variation through the creation of a composite indicator. Social Indicators Research, 123(2), 431-457. 